\title{
Reinventar el indio después de la Independencia: las representaciones del indígena en el Perú decimonónico (1821-1879)
}

\section{Maud Yvinec}

\author{
(2) OpenEdition \\ Journals \\ Edición electrónica \\ URL: http://journals.openedition.org/bifea/4087 \\ DOI: $10.4000 /$ bifea.4087 \\ ISSN: 2076-5827 \\ Editor \\ Institut Français d'Études Andines
}

Edición impresa

Fecha de publicación: 1 agosto 2013

Paginación: 287-293

ISSN: 0303-7495

\section{Referencia electrónica}

Maud Yvinec, "Reinventar el indio después de la Independencia: las representaciones del indígena en el Perú decimonónico (1821-1879) », Bulletin de l'Institut français d'études andines [En línea], 42 (2) | 2013, Publicado el 08 agosto 2013, consultado el 05 noviembre 2020. URL : http:// journals.openedition.org/bifea/4087 ; DOI : https://doi.org/10.4000/bifea.4087

\section{(c)}

Les contenus du Bulletin de l'Institut français d'études andines sont mis à disposition selon les termes de la licence Creative Commons Attribution - Pas d'Utilisation Commerciale - Pas de Modification 4.0 International. 


\title{
Reinventar el indio después de la Independencia: las representaciones del indígena en el Perú decimonónico (1821-1879)
}

\author{
Maud Yvinec ${ }^{*}$
}

El presente artículo expone los principales ejes de investigación de una tesis doctoral sobre las representaciones del indígena en el Perú decimonónico - siendo entendidas las representaciones no como contraposición a la realidad sino como estrategia simbólica encaminada a ordenar la estructura social y construir la identidad de distintos grupos al interior de esta (Chartier, 2009: 75-98)—.

El período analizado abarca desde la guerra de Independencia hasta la guerra del Pacífico, momento que ha sido muy poco estudiado en lo que respecta a la imagen del indio, a pesar de ser una época clave para los procesos de integración y exclusión en el Perú republicano. Corresponde, en efecto, al primer momento de construcción de la nación, vale decir, al momento en que se «imagina una comunidad»(Anderson, 1991), lo cual significó una necesaria reinvención del «indio». A los pocos días de declarar la Independencia, San Martín decretó que ya «no se denominar[ía] los aborígenes, indios o naturales» sino «peruanos», por ser ellos «hijos y ciudadanos del Perú». Así se suprimía la división jurídica colonial entre la «república de españoles» y la «república de indios», suponiéndose reunidas las poblaciones blanca e india en un solo cuerpo de nación. Sin embargo, medio siglo después, la derrota peruana frente a Chile en la Guerra del Pacífico evidenció el fracaso de la integración de los indígenas y motivó el surgimiento de algunas críticas frente a la situación de exclusión en la que los mantenía la República: de ahí el nacimiento del indigenismo peruano, estrechamente vinculado a las figuras de Manuel González Prada en la ensayística y Clorinda

* Investigadora asociada al IFEA, candidata a doctora en estudios latinoamericanos de la universidad París 3, profesora de civilización hispanoamericana en la universidad Rennes 2. 
Matto de Turner en las letras. Resulta que existen muchísimo más escritos, y, por ende, muchísimo más fuentes, sobre los indígenas peruanos a partir de finales del siglo XIX o inicios del XX y en adelante. Dichos escritos más contemporáneos sobre los indígenas — por lo general, indígenas de tierras altas — fueron entonces examinados a la luz de la historia o la filología, mientras que los textos anteriores parecen hasta hoy casi ignorados, especialmente por la historia sociocultural, si exceptuamos algunos trabajos sintéticos enfocados en el análisis de las ideas de la élite peruana decimonónica (Kristal, 1989; Andrés García, 2007). La tesis se interesa en esta olvidada época, postulando que ahí deben buscarse las raíces de las representaciones del indio en el Perú contemporáneo. Para ello no pretende identificar la mentalidad de determinadas clases sociales, sino basarse en el estudio de «series de discursos» — en tanto portadores de representaciones_ identificadas en función de sus diferentes condiciones de producción y posibilidad (Foucault, 1971). El trabajo se basa en textos formalmente tan diversos como la legislación, los discursos políticos e informes oficiales, la prensa, la literatura, la historiografía y algunos ensayos.

¿Cómo es imaginado el indígena en el momento en que el Perú se construye como nación? A continuación se presentarán cuatro tipos de representaciones que hemos identificado y que tratan de profundizar de alguna manera la ya famosa dicotomía «incas sí, indios no» (Méndez, 1993).

\section{EL INDIO DEL PASADO}

Esta primera parte empieza subrayando la herencia colonial en la conformación del discurso independentista y posindependentista sobre el indio del pasado. El patriotismo criollo colonial, que se respaldaba en la exaltación del pasado prehispánico como búsqueda de reconocimiento de la Corona frente al menosprecio de los peninsulares, se convierte en una manera de legitimar la emancipación de España e inventar una nueva identidad, lo que corresponde al proceso de «identificación de los antepasados» que caracteriza a todas las construcciones nacionales (Thiesse, 1999: 19).

Luego de esta introducción general, se estudia la utilización del referente incaico en el Perú del período 1821-1879, a través del análisis de discursos políticos, científicos, y literarios.

En lo político, se observa que la apelación al pasado inca es una constante de la prensa partidista, no solamente la prensa patriota de los años de la Independencia, como ya lo mencionaron muchos historiadores, sino también en los periódicos de opinión de los años posteriores, al contrario de lo que se suele suponer. En los años 1830-1840, los caudillos de turno utilizaron la referencia al «suelo de los incas» en los conflictos internacionales para exaltar el nacionalismo - mientras que sus mismos enemigos se situaban a veces en el territorio del antiguo Tawantinsuyu - así como también utilizaron la referencia a «las sabias leyes de los incas» en los conflictos nacionales para justificar sus proyectos —fuesen 
conservadores (Gamarra, Salaverry) o liberales (Orbegoso). A partir de mediados de siglo, la vuelta al hispanismo no impidió que resurgiera con bastante frecuencia la apelación al pasado incaico, en particular durante la guerra contra España en 1865, o en ocasión de cualquier ceremonia nacional.

Si el partidismo político constituye el primer discurso sobre la nación, poco a poco se mezcla con la prédica de la «civilización». En este marco, se analiza el discurso científico que se desarrolla a partir de los años 1850-1860: la Historiografía con Córdova y Urrutia, Lorente o Rivero; los inicios de la Arqueología con Rivero y Tschudi; la Lingüística con Pacheco Zegarra o Fernández Nodal. Los sabios peruanos se empeñaron en demostrar los aspectos «civilizados» del mundo incaico para poder imaginar un futuro nacional aún más avanzando en la vía del progreso, según la concepción positivista de la historia. Hicieron del pasado prehispánico la base de una nación civilizada a la cual no pertenecían los indígenas de la época republicana (concepción de una «degradación», no necesariamente irremediable). Finalmente, se examina el discurso literario, que se aparta del científico precisamente en el siglo XIX. Al no pretender transcribir hechos verdaderos, la literatura puede «inventar» el pasado con más libertad. Desde luego, se presta una particular atención al romanticismo, ya que cultiva, más que otras corrientes literarias, los temas históricos indígenas, sea en poemas (C. Althaus, C. A. Salaverry, C. Carrasco), leyendas (R. Palma en su primera época, A. Márquez, C. Freire de Jaimes, R. Rossel) o dramas (Salaverry). Los temas indígenas confieren un toque de color nacional a los temas universales del romanticismo, constituyen un modo de expresar el patriotismo, y permiten pensar la comunidad que se está construyendo (a través de los amores complejos entre conquistadores e indias, por ejemplo). Sin embargo esta visión nacional del indio no conlleva una visión cercana. Al contrario, se trata de una visión doblemente lejana, por la distancia geográfica (exotismo imitado de los europeos) y la distancia temporal (pasado alejado de los problemas presentes).

En suma, si el pasado indio se reivindica, no parece vinculado con la imagen del indio bajo la República, objeto de las tres siguientes partes.

\section{EL INDIO PROYECTADO}

En esta segunda parte se analizan el rol que se asignó a los indígenas dentro del proyecto nacional.

En primer lugar, se recuerda la voluntad de convertir al indio en ciudadano. Basándose en la concepción moderna del ciudadano-individuo abstracto, los legisladores del siglo XIX siempre trataron de no excluir a los indígenas como tales. En la época de la Independencia, San Martín y Bolívar promulgaron una serie de decretos que suprimían todas las diferencias coloniales entre indios y no-indios: abolición del trabajo forzado, del tributo, supresión de la comunidad e instauración de la propiedad privada. A lo largo del período estudiado, tanto en las (numerosas) constituciones, como en los códigos civiles (proyecto de código 
de Vidaurre en 1827, código de la Confederación Perú-Bolivia en 1838, y código de 1852), el «indígena» no figuraba como categoría específica. Por lo demás, los indios siempre tuvieron derecho a votar. Solamente quedó la cuestión del tributo, que se restableció en 1826, hasta que lo aboliera Castilla en 1854, y antes de nuevas tentativas para restablecerlo. Ahora bien, al analizar detenidamente los textos sobre el tema, se nota lo siguiente: cuando lo suprimen, los políticos utilizan el término colonial «tributo»; cuando lo restablecen, utilizan el término no tan connotado de «contribución». Esto evidencia el intento de no mostrar algo que pueda apartar a los indios.

La concepción del indígena como posible ciudadano implica un deseo de transformación. Si bien hubo proyectos de inmigración europea, en el Perú no se llevaron a cabo a gran escala antes de fines del siglo XIX. Por eso no hubo importantes proyectos de «blanquear» la población. Lo que más bien se postuló fue la «civilización», es decir la europeización, en particular a través de proyectos de educación, desde R. Castilla hasta M. Pardo. Este último emprendió en los años 1870 una vasta política de modernización que incluía la construcción de ferrocarriles para desenclavar los Andes y llevar la civilización a los indígenas. Todo ello permite resaltar la contrapartida del proyecto de indio-ciudadano: la homogeneización. Demuestra que la comunidad peruana imaginada era más bien una nación «desindianizada», no en el sentido de eliminar físicamente al indio, sino en el sentido de europeizarlo.

A título de ejemplo, se comprueban algunas maneras de ocultar al indígena en el momento de proporcionar una imagen de la nación. Muy relevantes son las relaciones de fiestas, especialmente en la prensa oficial, de Lima y de provincia: en las relaciones de fiestas tradicionales, asociadas al pasado colonial que debe desaparecer (corridas, determinadas fiestas religiosas), siempre se menciona al indígena, mientras que en las relaciones de fiestas cívicas, asociadas al presente republicano, no se habla del «indio» sino del «pueblo»-quedando clara la presencia de indígenas en dicho «pueblo» si se trata de regiones andinas-.

\section{EL INDIO PRESENTE}

Si bien se fantasea con una nación no indígena, nunca se escapa de su presencia. Esta tercera parte evidencia cómo se sigue apartando al indio como Otro.

Primero se demuestra que la legislación decimonónica resulta más ambigua de lo que parece. No solo porque se cobró la contribución de indígenas, o sea el antiguo tributo colonial, hasta 1854, lo que de hecho separaba a los indígenas de los no-indígenas, sino que también en muchos decretos y leyes hubo maneras de considerarlos distintos. Pese a los fundamentos del sistema republicano que no reconoce la «diferencia de clase» entre los ciudadanos, algunos textos oficiales siguieron mencionando la «clase indígena» —aunque fuera para conceder privilegios (decretos sobre el tipo de papel sellado, los pasaportes, etc.) —. Resalta la persistencia de estatutos y clasificaciones coloniales, como la calificación de 
«persona miserable» en varios decretos relativos a los indios, y la separación entre «españoles» (o «personas decentes»), «castas», e «indios» en varios registros parroquiales.

A ello deben añadirse las reticencias a aplicar las leyes republicanas. En la prensa se observan repetidas quejas contra el derecho de voto de los indígenas (el indio vota mal), la abolición del tributo (no trabaja si no está obligado), etc. Por lo demás, la legislación nacional no siempre se aplicaba a nivel regional: a veces se interpretaba, hasta se desviaba. Pretextando por ejemplo alguna «necesidad», los prefectos solían requerir que los indios trabajasen como postillones mientras que estaba terminantemente prohibido. Inclusive hemos encontrado decretos departamentales anticonstitucionales e ilegales, como el decreto de un prefecto de Puno que en 1846 decidió restablecer el trabajo forzado de los indígenas. Lo que prueba que más allá de la diferencia entre teoría y práctica, hubo algunas oposiciones al interior del mismo discurso oficial sobre los indígenas.

El indio no deja de considerarse como Otro. La mayor manifestación de ello es, obviamente, el desprecio que se destaca de la mayoría de los escritos (prensa, literatura costumbrista...). La alteridad se construye a través de la fijación de un tipo (o estereotipo). El indio es serrano, pobre, borracho, sucio, ignorante, pasivo... Esta representación es, por una parte, heredada de la época colonial y, por otra, se asemeja a la representación del plebeyo en las sociedades europeas del siglo XIX (se puede comparar, por ejemplo, con la representación del pueblo en las novelas de Michelet o Zola), cuando no a la representación de cualquier subalterno.

Marca por excelencia del desprecio, el insulto constituye finalmente un eje interesante de estudio de la Otredad. En la prensa como en algunos ensayos, notamos que la gente se ofende al ser considerada india (los limeños no quieren ser considerados indios por los extranjeros, los serranos no quieren ser considerados indios por los limeños). Por eso «indio» era una manera recurrente de criticar a un enemigo político: existe una gran cantidad de ejemplos, desde Gamarra o Santa Cruz cuyos orígenes indígenas fueron un objeto famoso de burla, hasta personajes locales menos conocidos como un tal Valentín Orihuela cuyo apodo era «valentindio-rihuela».

\section{EL INDIO PROBLEMA}

El menosprecio no es siempre incompatible con la preocupación por la situación de los indígenas. En efecto, el desprecio general no impidió que se elevaran voces, aunque tímidas, para defenderlos: éste es el objeto de esta última parte.

La emergencia de una «cuestión indígena» no puede sino analizarse de manera cronológica.

En las primeras décadas republicanas, los problemas económicos (deudas de las guerras de Independencia) y políticos (guerras civiles entre caudillos) impidieron que se focalizara el interés en los indios. Después de las acciones de los Libertadores, la cuestión se consideró resuelta, y ya no se habló mucho de los indios durante 
dos décadas. El poco interés que existió fue un interés provincial, pues los únicos textos periodísticos que toman la defensa de los indígenas durante ese período son artículos de la prensa liberal arequipeña o ayacuchana. Al respecto, cabe citar un ensayo de treinta páginas publicado en Arequipa libre en 1828. No obstante este artículo termina concluyendo que «hay otras materias que tratar, propias del tiempo». Pasa lo mismo con los cinco números de El indígeno [sic] a inicios de los años 1830.

Fue solamente a partir de mediados de siglo, gracias a la relativa bonanza económica (época del guano) y la relativa estabilidad política (época de R. Castilla), cuando pudo despertarse alguna preocupación por los indígenas. Entre las primeras denunciaciones de su condición, debe mencionarse la novela El Padre Horán, escrita por N. Aréstegui y publicada en 1848 en el Comercio bajo la forma de un folletín. Es una novela de costumbres que, al situarse en el Cusco del siglo XIX, pone en escena a personajes indígenas, y reclama la abolición del tributo. Sin embargo, esta novela, considerada por muchos críticos como la primera novela indigenista peruana, tampoco realza mucho a los indígenas, pues estos son personajes secundarios, y su defensa tiene muchos límites. Otras obras literarias notables son las novelas cortas publicadas en La Revista de Lima a inicios de los años 1860, pero se trata de una denuncia que no supera la compasión.

La preocupación por los indígenas se hace realmente más patente a finales de los años 1860, a raíz de la rebelión de Huancané (1867-1868), primera rebelión indígena importante de la época republicana. El puneño Juan Bustamante, un comerciante de lanas adinerado y gran viajero, nombrado apoderado de los indios de Huancané, fundó la Sociedad Amiga de los Indios. Dicha sociedad, que existió entre 1867 y 1870, reunió a una amplia élite liberal, tanto de Lima como de provincia. Gracias al análisis de la prensa (artículos de opinión y novelas de folletín hasta la fecha totalmente desconocidas), se demuestra que la rebelión de Huancané hizo rebrotar el miedo al indígena (latente desde la gran rebelión de Tupac Amaru) y desembocó paradójicamente en el primer movimiento de defensa de este. Por las semejanzas con algunos movimientos posteriores, se postula que se puede considerar como un proto-indigenismo.

\section{A MODO DE CONCLUSIÓN...}

La prolongación es evidente. De hecho, algunas de las ambigüedades relativas a las representaciones del indígena que se acaban de señalar parecen vigentes hoy en día. Entender el Perú republicano implica sin duda remontarse a la primera etapa de construcción nacional. 


\section{Referencias citadas}

ANDRÉS GARCÍA, M., 2007 - Peruanos e Indios: la figura del indígena en la intelectualidad y política criollas (Perú, siglos XVIII-XIX), 382 pp.; Sevilla: Universidad Internacional de Andalucía (UNIA).

ANDERSON, B., 1991 - Imagined communities: reflections on the origin and spread of nationalism, 224 pp.; Londres: Verso.

CHARTIER, R., 2009 - Au bord de la falaise. L'histoire entre certitudes et inquiétude, 384 pp.; París: Albin Michel.

FOUCAULT, M., 1971 - L'ordre du discours, 82 pp.; París: Gallimard.

KRISTAL, E., 1991 - Una visión urbana de los Andes: génesis y desarrollo del indigenismo en el Perú, 1848-1930, 224 pp.; Lima: Instituto de Apoyo Agrario.

MÉNDEZ, C., 1993 - Incas sí, indios no: apuntes para el desarrollo del nacionalismo criollo en el Perú, 27 pp.; Lima: Instituto de Estudios Peruanos (IEP).

THIESSE, A.-M., 1999 - La création des identités nationales : Europe XVIIle - XXe siècles, 302 pp.; París: Seuil. 